ARTICLE

DOI: $10.1057 /$ s41599-018-0184-7

\title{
Givenness and existence: On the possibility of a phenomenological philosophy of religion
}

\author{
Nikolaas Deketelaere ${ }^{1}$
}

\begin{abstract}
The so-called theological turn in recent French phenomenology has been the subject of a heated debate in France and elsewhere. This article outlines a possible future for this movement by considering the possibility of a phenomenological philosophy of religion distinct from a phenomenological theology. It argues that Jean-Luc Marion's phenomenology of givenness does not establish this possibility, as it aims at a theophanic experience and is therefore ultimately inscribed within a logic of faith. It is then with Jean-Luc Nancy's phenomenology of existence that a more plausible, though undeveloped, possible future for phenomenological philosophy of religion comes into view: not aimed at theophany (from faith), but rather at, what the article calls, the existential situation that facilitates or inhibits religious experience (about faith). This, the article argues, is the only way of limiting phenomenological philosophy to the possibility of revelation, leaving it to theology to consider the actuality of Revelation, as Marion deems necessary. It is thus also the only way for a phenomenological philosophy of religion to have a future as distinct from theology, that is to say, for it to be possible to speak phenomenologically about religious experiences regardless of whether this is done from a position of faith or not. In establishing this possibility, the article will emphasise the often neglected phenomenological and existential aspects of Nancy's thought.
\end{abstract}

\footnotetext{
${ }^{1}$ Balliol College, University of Oxford, Oxford, UK. Correspondence and requests for materials should be addressed to

N.D. (email: nikolaas.deketelaere@balliol.ox.ac.uk)
} 
To hear (hören) God's word does not mean to wander around the distant lands of metaphysics, but finally, at long last, to come to oneself, to learn to see oneself, to be revealed and become apparent (offenbar werden) to oneself, as one really is: belonging to God ( $z u$ Gott gehörig) and therefore so very worthy of questioning (fragwürdig).

- Barth 1982, p. 516.

\section{Introduction}

n his 1988 essay 'The Possible and Revelation' (2008a [1988]: p. 1), Jean-Luc Marion raises one of the most controversial questions of contemporary French philosophy: "Can phenomenology contribute in a privileged way to the development of a 'philosophy of religion'? In other words, can 'philosophy of religion' become a 'phenomenology of religion'?” The essay also contains Marion's first articulation of the idea of the saturated phenomenon, a phenomenon so rich in intuition that it overwhelms any possible intentional horizon. He thus introduces a new mode of phenomenality, characterised by excessive intuitive givenness. Marion's move is controversial, however, for it identifies this new mode of phenomenality with "the regime of revelation" (2008a, p. 16), and understands the revelation of Christ as "the preeminent saturated phenomenon" (2017a, p. 142), placing religious phenomena at the heart of phenomenology.

Some see this as a derogation of the phenomenological method. In his 1991 book The Theological Turn in French Phenomenology, Dominique Janicaud describes with concern how Marion is part of a larger movement, including Emmanuel Lévinas, Michel Henry and Jean-Louis Chrétien. According to Janicaud, these authors abandon the phenomenological method and philosophy altogether, for at its core stands the exclusion of any transcendence: he speaks of a veering of phenomenology, off the road of philosophy, ending up the ditch of theology (2000 [1991], p. 50-69). Bernard Prusak sums it up elegantly by suggesting that "Janicaud inverts the scenario of Plato's Apology: he indicts Lévinas et al. for corrupting the future of French philosophy by introducing into phenomenology a god-the biblical god-who does not belong there" (2000, p. 4).

This article explores whether this theological turn really does corrupt the future of French philosophy. Or more precisely, and this is Marion's question, I consider whether a distinctly philosophical phenomenology of religion, as opposed to a phenomenological theology, is possible. I proceed in three steps. I first give a broad overview of the present phenomenological landscape in France and present my argument in general terms: that the separation between a phenomenological philosophy of religion and a phenomenological theology is formed by a difference in the existential situation in which phenomenological reason finds itself (faith or unfaith). As such, the question of a phenomenological philosophy of religion must concern the phenomenological implications of this existential situation of reason: it must be about faith, whilst phenomenological theology comes to experience from the situation of faith. Subsequently, I give a critical summary of how Marion relates phenomenology to theology, drawing on his early essays where this issue is at stake. ${ }^{1}$ I argue that Marion's phenomenology is ultimately inscribed within a logic of faith because it aims at theophany and is thus a phenomenological theology rather than a phenomenological philosophy of religion. Finally, I turn to Jean-Luc Nancy, who presents a more plausible, though undeveloped, possible future for phenomenological philosophy of religion: not aimed at theophany (from faith), but rather at the existential situation that facilitates or inhibits religious experience (about faith). That is to say, the task of a phenomenological philosophy of religion is to consider how faith structures experience and in doing so makes religious experience possible, irrespective of the uncontested actuality of this experience (or its theophanic character). A phenomenological theology, however, assumes the actuality of religious or theophanic experience, in virtue of the fact that it comes to experience from a standpoint of faith, and proceeds to describe it phenomenologically.

\section{\$1. The phenomenological conception of reason}

a. Theological intimidation and philosophical assertion. Much scorn has been pored over the theological turn from various angles (e.g., Vattimo, 2016; O'Leary, 2018). Yet, no denunciation is more polemic than Janicaud's. He boldly declares that "phenomenology has been taken hostage by a theology that does not want to say its name" (2000, p. 43). Not that there is anything wrong with theology, he quickly adds, but it simply does not belong within phenomenology, for this would be contrary to the phenomenological method as set out by the founder of phenomenology, Edmund Husserl.

That method rests on "a certain refraining from judgement" (Husserl, 1982, p. 55), known as phenomenological reduction or epoché, regarding the external world. In our daily lives, we assume that our experience is tied to a world existing independently of our experience. Yet, we have no foundation for this assumption, so we must temporarily reduce or bracket it (Husserl, 1982, p. 54). This is the first step to fulfilling Husserl's battle-cry for philosophy to be a rigorous science by going "back to the 'things themselves"' (2001, p. 168). By bracketing our presuppositions, we achieve a level of cognition that has the right to serve as the certain starting point for philosophy, namely lived experience (Erlebnis). This criterion, which Husserl calls the principle of principles, guarantees philosophy's scientific rigour: "that every originarily giving intuition is a source of right for cognition, that everything originarily (so to speak, in its 'personal' actuality) offered to us in 'intuition' is to be accepted simply as it gives itself out to be, but also only within the limits in which it is given there" (1982: p. 43 trans. mod.). Phenomenology thus always starts from a position of radical immanence, only allowing transcendence insofar it appears within the immanence of consciousness.

Hence, Bruce Ellis Benson sums up the phenomenological attitude, achieved through reduction, succinctly as "an orientation in which the object is immanently given to a neutral consciousness" (2010, p. 2). This definition captures two ideas that Janicaud sees as obstacles to a phenomenology of religion: first, the exclusion of divine transcendence from phenomenality; and, second, the phenomenologist's neutral attitude in describing experience objectively. For example, experientially, a religious experience might very well be identical to a delusion, even though only one is qualified as referring to God. ${ }^{2}$ That ontological qualification, however, should be reduced because it refers to a transcendent reality outside of lived experience: God is not given in experience, he does not appear. When philosophers like Marion unscrupulously recognise certain experiences as revelation, they are committing "strict treason of the reduction," says Janicaud, by imposing an ontological assumption (that a certain experience refers to God) or a personal attitude (faith), on experience "to render phenomenological what cannot be" (2000, p. 27, p. 62). Yet, “in virtue of what experience?" (Janicaud, 2000, p. 27). Does Marion have a phenomenological criterion to recognise saturated phenomena as revelation, as opposed to a theological one? Janicaud believes the latter is the case (2000, p. 27): in allowing for the phenomenon of revelation, "theology (...) 
installs itself at the most intimate dwelling of consciousness, as if that were as natural as could be. Must philosophy let itself be thus intimidated?"

Janicaud is bewildered by his colleagues' "strange stubbornness" to do what cannot be done: "Between the unconditional affirmation of Transcendence and the patient interrogation of the visible, the incompatibility cries out; we must choose" (2000, p. 26, p. 33). Now, Marion is certainly aware of this: insofar as the phenomenological method is applied to religious experience, he says, "it would be a question either of addressing phenomena that are objectively definable but lose their religious specificity or of addressing phenomena that are specifically religious but cannot be described objectively" (2008b, p. 18; 2008a, p. 12). Experience can either be religious, or it can be scientifically described; it cannot be both. For Janicaud, the new phenomenologists' supposed ignorance of this dilemma makes them guilty of "methodological slacking off," caused by a creative and religious zeal that "made them neglect what there was to respect in the Husserlian concern for rigour" (2000, p. 91). As he is fond of declaring: phenomenology and theology make two, and one must choose (2000, p. 99-103).

Yet, insofar as Janicaud suggests that these phenomenologies are an "expropriation of the phenomenological house and its methodological instruments" (2000, p. 33-34), he is unfairly misrepresenting them. As has been repeatedly pointed out (de Vries, 1999; Welten and Jonkers, 2005), the interest in religious phenomena derives from a distinctly phenomenological concern, a desire for phenomenological radicality; rather than from reasons that are primarily theological. For the new phenomenologists, the religious phenomenon pushes phenomenality, and with it phenomenology, to its limits (and its heart), generating new phenomenological insights. The theological dimension would thus fulfil a purely heuristic, rather than teleological, role.

Marion himself sets up his project in this way, suggesting that "the religious phenomenon poses the question of the general possibility of the phenomenon" (2008b, p. 18). It offers a hitherto overlooked yet primordial form of phenomenality that the phenomenological ethos, as a fundamental openness to whatever shows itself, requires us to pick up: "more than posing a question for phenomenology," as Jeffrey Kosky puts it, the religious phenomenon "poses the question of phenomenology itself-of its limits and the criteria it uses to determine phenomenality" (2000, p. 113). In that sense, the new phenomenology has also been called radical phenomenology (e.g., Holzer, 1999): phenomenology of religion, rather than turning away from phenomenology and philosophy, would then exist in a profound realisation of its aims and method. Hence, Marion suggests, "the question of the possibility of a phenomenology of religion," is now "posed in terms that are simple if not new (for it is only a matter of pushing the phenomenological intention to its end)" (2008b, p. 48). Marion thus wholehearted agrees with Janicaud that phenomenology and theology make two: he may be breaking with the phenomenological tradition, but only to realise its aims. For him, the saturated phenomenon of revelation is first and foremost to be studied phenomenologically, which need not involve any theology. Yet, what Janicaud accuses Marion and his colleagues of is nevertheless the exact opposite. Who are we then to believe when it comes to the relationship between phenomenology and theology within phenomenology's theological turn?

b. Existential situation. Aaron Simmons eloquently sketches a middle way between these two extremes. First, he says, Janicaud's critique is hypocritical: in speaking of the theological intimidation of phenomenology, Janicaud is himself abandoning the purely phenomenal field, for "to delimit the domain of phenomenological enquiry from the outset is to already resist the supposed neutrality of the phenomenological method" (Simmons, 2010 , p. 18). What Janicaud calls neutrality, is really an arbitrary restriction of the phenomenal field, itself phenomenologically illegitimate because it involves a presupposition: based solely on the phenomenological criterion of the principle of principles, we must recognise religious phenomena if they actually do appear. Thus, "instead of offering an innocuous method of neutrality, what Janicaud does is to just as problematically place out of bounds that which he does not want to find later in the middle of the playing field" (Simmons, 2010, p. 24). Marion similarly complains that Janicaud's "denunciation-more virulent than argued," is dogmatic because it presupposes that there is a body of phenomenological orthodoxy that coincides with Husserl's transcendental period: "None of these points is self-evident," he points out, "especially insofar as it belongs essentially to phenomenology that the a posteriori render it possible and therefore that no a priori prohibition predetermine it" (2008c, p. 59-60). Here we clearly see how Marion is "interrogating phenomenological orthodoxy, but doing so perhaps in the name of an attempt to be orthodox" (Simmons and Benson, 2013, p. 133). Hence, these new phenomenologies must at least prima facie be considered to be philosophically legitimate, as opposed to an abuse of phenomenological reason by theology. Yet, Simmons is also surprised by the eagerness of some to consider these phenomenologists to be philosophers and not theologians, as this would imply that theology is not at home in phenomenology (2010, p. 23; 2011, p. 158): "must it be the case that phenomenology can't be theologically concerned precisely as phenomenology?" Have we no need for theology to understand revelation and do these phenomenologies teach us nothing about what it means for God to reveal himself?

Simmons' point is exactly that it is not an either-or situation: though the prime concern of these phenomenologists is to think "the general possibility of the phenomenon" (Marion, 2008b, p. 18 ); these insights are relevant to theology too, for that general possibility rests on the particular possibility of the religious phenomenon. The idea that any position could be neutral and devoid of presuppositions, as Janicaud and Marion both claim, is itself, paradoxically, an extra-phenomenal presupposition that must be reduced (Simmons, 2010, p. 24). As Søren Kierkegaard might put it, they both make the mistake of forgetting that they exist (2009, p. 44). The neutral point of view is never itself phenomenally given: I never experience the world from a transcendental perspective that isn't one; yet, I am intimately familiar with my own perspective that brings the world into (a) view. John Caputo, for example, points out that "the truth is gained not by approaching things without presuppositions-can you even imagine such a thing?-but by getting rid of inappropriate presuppositions (frame) and finding appropriate ones, the very ones that give us access to the things in question" (2013, p. 182). Phenomena appear, not by bracketing all possible presuppositions, but by only admitting those that allow phenomena to appear to $m e^{3}$

Simmons suggests that theology and phenomenology are distinct because they rely on different sources; yet, neither being neutral, they share their reliance on a "deep situatedness of rationality itself," or presuppositions that constitute a particular discourse or discipline as such and give it its distinctive perspective on the world (Simmons, 2010, p. 27-28). For him this situatedness reflects the community of discourse in which reason operates and by which it is determined. This community institutes itself by means of a decision that determines what counts as rational discourse within that community (Simmons and Benson, 2013, p. 109-111; Simmons, 2010, p. 27-28; 2011, p. 153). Crucially, an extra-phenomenal (even extra-rational) 
element constitutes phenomenality (and rationality): when phenomenology is but a particular rational method, religious phenomena are perfectly commonplace amongst theologians, in virtue of the biases reason needs to operate in that community; whilst recognising such phenomena might be the height of irrationality, treason of the reduction, when that same reason operates within the philosophical discourse community, according to different biases. Yet, reason cannot operate in a void: something only appears as rational in relation to something else. It is this question of what constitutes appearance as that has always been the phenomenological one, and the situadedness of reason is therefore of crucial phenomenological importance.

However, understanding reason's situation in terms of discourse communities risks putting too strong an emphasis on the different sources or authorities of philosophy and theology, rather than their respective ways of experiencing the world. Simmons' idea that phenomenological reason is situated, put inthe-world, by an extra-rational decision, can be alternatively formulated through Kierkegaard's understanding of subjectivity as the site of decision $(2009$, p. 163, p. 171$) .{ }^{4}$ By this, he means that it is in $m y$ subjectivity that the world opens up as what it means to me. "We are always 'situated', and that situation imposes a limit on us," as Caputo puts it, "but that limit also gives us an angle of entry, and approach, a perspective, an interpretation. God doesn't need an angle, but we do. Having an angle is the way truths open up for us mortals" (2013, p. 13). Thus, phenomenological reason is always existentially situated: phenomena only appear in terms our subjective relation to the world, our being-in-it. Hence, neither Marion nor Janicaud have abandoned phenomenological rationality, it is merely situated differently. Comparing these different existential situations is in itself a question, if not the question, of phenomenology.

As such, phenomenology is an appropriate method for theology, since it is just that: a method, a specific deployment of reason. Not all philosophy is phenomenological, and not all phenomenology is philosophical. There is no (phenomenological) reason to exclude prima facie the possibility of a phenomenological theology. This is Marion's approach too: "Some would like to leave a choice only between philosophical silence and faith without reason. (...) Yet outside of revealed theology there is no reason to prohibit reason-here, philosophy in its phenomenological bearing-from pushing reason to its end, that is, to itself, without admitting any other limits than those of phenomenality" (2008c, p. 61).

That is, if the claim that the religious phenomenon embodies some fundamental mode of phenomenality holds true. Indeed, one element of Janicaud's critique has not yet been rejected: in virtue of what experience? If Marion's phenomenology is a phenomenological philosophy of religion, as opposed to a phenomenological theology, then the religious qualification of the experience cannot be faith-dependent. The legitimacy of Marion's phenomenology of religion, as analysis of religious phenomena, is thus not in dispute. Whether it is justified as philosophy or rather as theology, that is the question. Let us therefore now explore that phenomenology.

\section{\$2. The theophany of givenness}

a. Radical empiricism. Marion too understands phenomenology as beginning from the principle of principles or "the principle of nonpresuppositions" (2008c, p. 55). His starting point is thus perfectly orthodox, namely "to let what shows itself be seen from itself, just as it shows itself from itself” (Heidegger, 1996, p. 34). Indeed, Marion laments, if only Husserl and Heidegger would scrupulously stick to it themselves. They do not, because they fail to execute the reduction properly and to its end: Husserl reduces to objectness and Heidegger to beingness; but neither actually reduces to the appearing of phenomena. Marion therefore suggests a radical reduction to the mere givenness of phenomena: if the appearing of phenomena is what shows itself from itself, then "what shows itself first gives itself" (2002a, p. 5). Michel Henry, (2015) suggests that Marion has thus formulated a fourth principle of phenomenology, ${ }^{5}$ summarising all others and exposing the pure phenomenality of absolute givenness, namely: "so much reduction, so much givenness" (Marion, 1998: 203). This fourth principle has a subtle though important consequence:

This principle enacts a revolutionary advance because the answer to the question of right (...) will henceforth no longer come from an authority or a principle anterior to the phenomena themselves or different from them, but will depend solely on the fact of their real givenness (in the flesh) to intuition or not. The question of right allows for a response of fact: phenomena no longer need to be justified before a tribunal of reason, but are given as such. Givenness finds itself erected as the self-justification of the phenomenon as such: everything that is given to intuition and only what is given to intuition is real as a phenomenon (Marion, 2017b, p. 96).

By recognising givenness as principle of phenomenality, Marion collapses the question of the phenomenon's possibility de jure (its legitimacy as cognition) into that of its de facto possibility (its factuality as cognition). Givenness, as the only condition of possible experience, allows for the coincidence of the material and formal conditions of phenomenality: something counts as phenomenon when it is factually given; for when it is given, it is given in terms of givenness. Indeed, givenness, the mode of its appearing, is coextensive with the fact of its appearing, its givenness (Marion, 2002b, p. 17-23). Hence, the principle of givenness embodies the essence of the reduction: allowing whatever does show itself from itself, to be seen from itself (Marion, 2008a, p. 5). "The sole criterion in phenomenology issues from the facts," Marion says, "What shows itself justifies itself by that very fact" (2008c, p. 60). He thus believes to be simply stating the essence of the phenomenological method: namely, "a finally radical empiricism-finally radical because it is no longer limited to sensible intuition but admits all originarily giving intuition" (2008c, p. 57).

Indeed, Marion and Janicaud agree on what the phenomenological method is, but disagree on what it allows for. For Marion, too, phenomenology's radical empiricism means putting "in parentheses all transcendence, including that of God." Where they differ, however, is that for Marion "the question of God is played out as much in the dimension of immanence as in that of transcendence" (2002b, p. 24, p. 27). It is thus, again, a matter of the conditions within which phenomenological rationality operates: not of the logical validity of the inference, but of the status of the assumptions that inform it. Marion's point is that, insofar as religious phenomena give themselves, they must in principle be subject to phenomenological analysis: "religious phenomena would reappear again in philosophy, as facts justified de jure since given in fact (...)-all these lived experiences of consciousness would hence appear as phenomena by full right, at least to the extent to which they are given to consciousness" (2008a, p. 5; see also 2017b, p. 96). This accords perfectly with the phenomenological conception of reason. The question is whether the premise is true: whether religious phenomena do give (show) themselves, as (from) themselves. Let us therefore consider why this not traditionally thought to the case.

b. Possibility and experience. According to Marion, religious phenomena are justified in virtue of the principle of principles, 
yet classical phenomenology did not acknowledge this because its understanding of this principle was internally inconsistent: "not because intuition as such limits phenomenality, but because as intuition it remains framed by two conditions of possibility, conditions that themselves are not intuitive but that are nevertheless assigned to every phenomenon. The second and third traits of the 'principle of all principles' contradict the first, as conditions and limits-a condition and a limit-contradict the claim to absolute possibility opened by the giving intuition" (2008b, p. 22; 2002a, 184-189). Husserl may have exposed absolute givenness, but failed to acknowledge the coincidence of the material and formal conditions of phenomenality this implies: beyond proclaiming the supremacy of giving intuition, his principle also adds a second trait, a horizon, circumscribing the limits in which the intuition gives itself; and a third trait, the $I$ to which the intuition gives itself and by which it is constituted into a phenomenon.

These two additional traits undo the first trait's achievement, namely givenness' absolute character. Otherwise put, they contradict the criterion established by the first trait, namely the reduction: because they are exclusively formal, they are illegitimate; for the first trait abolished every formal condition irreducible to a material one. For classical phenomenology, "the possibility of the phenomenon results not from its own phenomenality," Marion says, "but from an authority that is marginal, other, if not external: that of the conditions of experience for and by the subject" (2002a, p. 181). It may have uncovered absolute givenness, "but it thinks that givenness only on the basis of determinations that threaten its originary character: the horizon and the reduction [to the I]. Phenomenology would thus almost immediately condemn itself to missing what the giving intuition indicates to it as its goal: to free the possibility of appearing as such" (Marion, 2008b, p. 24).

These two formal conditions also require the exclusion of religious phenomenona: it is the de jure exclusion of revelation, as the $a$ priori exclusion of absolute phenomena by the requirement of a limiting horizon, that makes its de facto appearance impossible. "By imposing an a priori dimension or abode and therefore a limit for revelation," Marion says, "the concept of the horizon itself disqualifies the possibility of revelation, while at the same time making any manifestation possible. The obstacles to revelation thus coincide with the conditions of manifestation" (2008a, p. 12). We must thus rethink the general conditions of possibility for the phenomenon and render them adequate to what Henry calls pure phenomenality, namely Marion's absolute givenness: conceptualising phenomenality such that in principle an absolute phenomenon can give itself absolutely, formally unconditioned. ${ }^{6}$ We must outline the mode of phenomenality where self-giving intuition alone "secures its condition of possibility," where "the phenomenality of givenness is indexed to intuition" (Marion, 2002a, p. 193). Ultimately, Marion says, this requires being able to think the phenomenon of revelation, and as such "the religious phenomenon poses the question of the general possibility of the phenomenon" (2008b, p.18).

"How then can a phenomenon that challenges any horizon appear in the horizon of a world?" Marion asks. "By saturating it" (2017b, p. 99). Here the famous saturated phenomenon comes in: a phenomenon so rich in intuition, because it gives itself absolutely without reserve, that it is in excess of any possible intentional horizon. As such, it "only appears by contradicting by excess the conditions of any appearance: its glory (doxa) is always exercised as a paradox, where evidence shows itself through bedazzlement" (Marion, 2017b, p. 99). It is exercised as a paradox because absolute givenness does not appear, since its nature exists in contradicting the conditions of appearance: "Givenness par excellence actually lays itself open to seeming to disappear (by defect) precisely because it gives itself without reserve (by excess)" (Marion, 2008c, p. 63-64). It is not what is seen, but rather the appearance of the invisible as the awareness that there is more to be seen than I can register, detected only "by the interference of its horizon, like the luminous rays that, by being reflected in the frame of a mirror, interfere with and hinder each other or, in contrast, gather their lights in an unbearable bedazzlement" (Marion, 2017b, p. 99). Hence, saturation allows for religious phenomena, such as revelation, to enter the phenomenal field: "Revelation entails a presentation. Hence it condescends to assume a horizon, but it nevertheless challenges any a priori condition imposed on its possibility. Even so these paradoxical requirements indicate the correct response: revelation presents itself in a horizon only by saturating it" (Marion, 2008a, p. 16). Revelation is not the appearance of something but rather the disruption of appearance, stunning anticipation: not experienced but making itself felt in the stunned subject of experience. Which brings us to the second condition: the $I$.

The third trait of the principle of principles, like the second contradicting the first, is that intuition only gives itself "to us," to an $I$ that constitutes what appears from what gives itself against a horizon. Or, differently put, a priori conditions of possible experience are always imposed on self-giving intuition by a subject (Marion, 2002a, p. 187). Hence, "even if it shows itself on the basis of itself," Marion says, "the phenomenon can do so only by allowing itself to be led back (réduit), and therefore reduced, to the I" (2008b, p. 23-24). The I's essential function is to control and condition givenness so that it can be constituted into an object. Here too, Marion asks (2002a, p. 189; 2008b, p. 24): "Can we imagine phenomena such that they would invert limit (by exceeding the horizon, instead of being inscribed within it) and condition (by reconducting the I to itself, instead of being reduced to it)?" Indeed, we can: the saturated phenomenon that, by giving itself absolutely, challenges the process of subjective constitution against the horizons it disrupts. Phenomena then constitute and impose themselves on a subject, rather than the subject imposing its conditions on phenomena to constitute them. The given, Marion says, "merits its name by its being a fait accompli, such that it happens to me, and in which it is distinguished from all foreseen, synthesised, and constituted objects, since it happens to me as an event" (2002b, p. 25). The direction of constitution is reversed: the event surprises me, I find myself constituted by it (je me suis fait), namely as witness to the event. In scrambling horizons, absolute givenness, "constituting its interlocutor as stunned (interloqué) and not as a phenomenon constituted by an $I$, takes up again a common phenomenological character, but here also by inverting it. It indicates the position of the $I$ that has become a $m e$ (moi): responding to a givenness rather than objectifying it" (Marion, 2017b, p. 100). It can then also be understood as witness to revelation, for when it comes to the subjective character of experience, the saturated phenomenon "divests the $I$ of any a priori character. This is commonly said as: Revelation reveals the I to itself" (Marion, 2017b, p. 100).

Marion thus places religious phenomena within reach of phenomenological reason as the general possibility of the phenomenon because it challenges phenomenologically illegitimate conditions of possible experience. Where classical phenomenology concerns what gives itself conditionally as something through constitution; Marion's radical phenomenology concerns what gives itself unconditionally by imposition. "The difference between these standpoints does not run between rationality and credulity," as Janicaud believes, "but between the recognition of occurrences (faits), even at the cost of their explanation, and the censoring of events (faits), even at the cost of real evidence, thus between empirical acceptance of an 'impossible' possibility and the banning on principle of the possibility of 'impossible' events" 
(Marion, 2017b, p. 90). Only this approach would be the radical empiricism that the phenomenological reduction requires.

c. Possibility and revelation. Phenomenology, Marion says, therefore succeeds where previous philosophy of religion failed: "freeing the possibility of revelation, hence possibility as revelation, from the grip of the (..) a priori condition of possibility (hence of impossibility) for any event to come" (2008a, p. 16-17). Revelation is an impossible possibility, there "where an authority that is transcendent to experience nevertheless manifests itself experientially" (Marion, 2008a, p. 2), experience that transcends the conditions of possible experience. Phenomenologically speaking, possibility precedes actuality. In Marion's framework, however, actuality precedes possibility: since revelation is "the phenomenon taken in its fullest meaning" (Marion, 2008b, p. 46), phenomenality is only limited by the actuality of experience, rather than a priori conditions regarding its possibility. Whatever gives itself in fact, is as possible phenomenon included in the phenomenal field by right as a matter of fact. ${ }^{7}$ Saturated phenomena thus do not put themselves into question by exceeding the conditions of possible experience the subject uses to make sense of the world, but rather put that subject into question together with his approach to the world.

What does this mean for the relationship between phenomenology and theology? Well, Marion says, "givenness radically redefines" it in terms of possibility (1990, p. 800). Marion, somewhat exasperated at having to make this point over and over again, explains:

Phenomenology describes possibilities and never considers the phenomenon of revelation except as a possibility of phenomenality, one that it would formulate in this way: If God were to manifest himself (or manifested himself), he would use a paradox to the second degree. Revelation (of God by himself, theo-logical), if it takes place, will assume the phenomenal figure of the phenomenon of revelation, of the paradox of paradoxes, of saturation to the second degree. To be sure Revelation (as actuality) is never confounded with revelation (as possible phenomenon). (...) But phenomenology, which owes it to phenomenality to go this far, does not go beyond and should never pretend to decide the fact of Revelation, its historicity, its actuality, or its meaning. (...) Only a theology, and on condition of constructing itself on the basis of this fact alone (...), could reach it. Even if it had the desire to do so (...), phenomenology would not have the power to turn into theology (2002a, p. 235n90).

Here, Marion distinguishes between Revelation and revelation. The former regards the actuality of religious experience: the historical event of God revealing himself, that he is given in fact (materially) to consciousness. The latter regards the possibility of such an event being experienced: the phenomenality this event takes on, outlining how such an event would be given (formally), regardless of whether it actually is. "Between phenomenology and theology," Marion says, "the border passes between revelation as possibility and Revelation as historicity" (2008c, p. 64). In relation to the religious phenomenon, phenomenology thus "exercises a purely and simply critical function, in a strictly Kantian posture" (Marion, 2002b, p. 28). Its task exists in developing the analysis performed in the previous paragraph: rendering phenomenality adequate to revelation. Indeed, as Falque observes, Marion performs "a quasi-transcendental deduction of revelation starting from the saturated phenomenon" (2007, p. 191). It is as such that Marion believes to have realised a phenomenological philosophy of religion that grounds phenomenology proper. d. Phenomenology and theophany. However, we cannot yet declare ourselves satisfied, for Marion's phenomenology of religion is also key to theology as the traditional praeambula fidei. Even within theology, to describe Revelation, Marion's phenomenological framework must first be imported precisely because possibility (phenomenology) precedes actuality (theology). "The topic of a phenomenology of religion," suggests James K.A. Smith, comparing Marion to Aquinas, "is precisely this theophany: what distinguishes it from theology is simply its mode of knowledge or perception." (1999, p. 22). If phenomenological philosophy of religion and phenomenological theology share the topic of theophany, then whether Marion's phenomenology is justified as theology or philosophy remains to be decided.

The ease with which some, when the possibility an absolute phenomenon has been admitted to in principle, identify it with theophany is somewhat curious. Kosky, for example, speaks in a single breath of the "properly religious phenomena of revelation, theophany," and contends that "insofar as revealed theology, the Scriptures, claims to describe certain appearings and manifestations, theophanies, it belongs within phenomenology" (2000, p. 116-118). Marion similarly states, in an "ultra-traditional manner" (Caputo, 2007, p. 84), that with absolute phenomenality "an experience, effectively beyond (...) the conditions of possibility of experience, is affirmed not only by its affidavit from privileged or designated individuals, but by words or expositions rightly accessible to everyone (e.g., the Scriptures). Revelation takes its strength of provocation from what it speaks universally" (2008a, p. 2).

Does this not confuse the phenomenological regime of revelation, a mode of phenomenality, with actual Revelation, a historically situated theophany? Only one of these is universally accessible. Even Falque, otherwise gleefully declaring that "the more we theologise, the better we philosophise" (2008, p. 35; 2016a, p. 147-149), warns that "contemporary phenomenology is indeed wrong to somewhat quickly identify phenomenality with revelation" (2006, p. 207). Moreover, he continues, "in the context of philosophy, one cannot so easily connect phenomenology and theophany," precisely because "the divine is not the primary object of the phenomenologist-at least inasmuch as he is (...) a philosopher first and foremost" (2016b, p. 217). If an absolute phenomenon were to actually give itself absolutely, it would still remain to be seen whether what it thus gives is God. ${ }^{8}$ Marion forgets that what is reduced in phenomenology is not just the actuality of theophany (Revelation), until only its possibility remains (revelation); rather, the reduction extends to the nature of theophany (theophaneia): that the appearing (phanein) would be that of divinity (theos). Marion's claim that Scripture renders descriptions of Revelation universally accessible strikes me as naïve: faith is indeed not required to accept the historical actuality of the experiences recorded in Scripture; it is, however, required to accept the theophanic character of these experiences, instead of dismissing them as (historically actual) illusions. As Caputo puts it: "Something is given, I know not what, that is intended as a presence of the risen Jesus in the community; it could also be intended as an hallucination if one does not have faith or has a different faith" (2007, p. 88). The reduction applies to theological realism, as it does to ontological realism: Marion's distinction between actuality and possibility works if it is operative within the object of experience, rather than the experience itself. Yet, this is not what he does. Caputo similarly complains that Marion's phenomenology is inscribed within a logic of faith:

It would be paganism to think that the divinity of Jesus would have been detectible (...). The Revelation is revelation that Jesus is the anointed one, not a revelation of the divinity, which no one can see and still live. The 
divinity is a matter of faith. By faith, we are given to believe that Jesus is divine, (...) but the divinity is not itself given. Even if you were standing right beside Jesus you would not see the divinity unless you believed it; and if you believed it, that is because you would not see it. You would believe it even though, indeed, in spite of the fact that you did not see it, which is what faith means $(2007$, p. 85).

The religious specificity of the religious phenomenon, so important to Marion, is thus still in question: we must not just be able to phenomenalise an absolute, but to phenomenalise the absolute (God) as God. This question is phenomenological, according to Marion's distinction, because it does not require God to actually reveal himself; it rather asks how God reveals himself when he gives himself as an absolute phenomenon.

We have thus returned to the only element of Janicaud's critique still standing: the self-revelation of God as phenomenological possibility, of course; but in virtue of what experience? Jocelyn Benoist (2001, p.102) similarly asks Marion: "what will you answer me if I say to you that where you see God, I see nothing?" He feels that Marion's phenomenology has not secured "the conditions of publicity necessary (...) to answer by means other than a ruse or the violence (...) of a reduction." Marion's answer is that "not seeing does not prove that there is nothing to see. It can simply suggest that there is indeed something to see, but that in order to see it, it is necessary to learn to see otherwise" (2008d, p. 123-124). He essentially tells Benoist to have another look and this time, please, a proper look: since the saturated phenomenon gives itself unconditionally, Benoist must simply not want to see it, stubbornly refuses to acknowledge what there is to be seen.

That argument is problematic, though. According to Marion, the faith that he has and Benoist lacks, does not allow one to compensate for a lack of intuition and thus to see God where others do not, as Benoist suspects (Marion, 2017a, p. 136; 2017b, p. 99). Rather, faith is the willingness to see what there is to be seen without prejudice, a fidelity to givenness: the subject does justice to the absolute givenness of the phenomenon by seeing otherwise, by abandoning his horizons and himself. Indeed, Marion understands "the will to see (le vouloir bien voir)," as deciding the actuality of phenomenalisation: "in order to phenomenalise the given, one first has to admit it (to 'want' to receive it) and receive oneself from it as given over to it so as thus to see (...) what it shows. The decision to respond, therefore to receive, precedes the possibility of seeing" (2002a, p. 305, p. 307). Hence, Benoist's inability to see simply indicates an unwillingness to see what there is to be seen. Though not seeing indeed does not mean that there is nothing to be seen, in dismissing Benoist's objection as bad faith (or a faulty will), Marion makes the same mistake he points out in others: namely, arbitrarily refusing to accept the actuality (or lack thereof) of certain experiences. Falque describes how Marion "pays a heavy price for his audacity," because absolute phenomenality, in "consecrating excess as standard, basically places the 'fault' of its nonphenomenalisation on a subject that is as impotent as it is faulty" (2003, p. 74). There is a moral dimension to this, summed up eloquently by Joeri Schrijvers: "the 'faulty will' is the absence of that which, properly speaking, ought to be there, the will to see the given. All nonphenomenalization of the given is understood as a lack, an unwillingness, or irresponsibility to see the given as given" (2011, p. 85). Not a lack of intuition, publicly accessible to anyone willing to see it; but a personal shortcoming of Benoist's. Therefore, Schrijvers continues, Marion confirms the objection, for his "response can only be violent or by ruse: when one (...) does not see the excessive intuition of the given, this (...) cannot be due to a hole in the theory (for instance: something is simply not given) but to the absence of a certain will that, properly speaking, ought to be there" (2011: 85). Marion does not, and indeed cannot, give a reason for his decision for givenness, but can only have faith: the decision must be groundless (extraphenomenal, extra-rational) because givenness is the ultimate ground and criterion (2002a: 307-308). Marion has faith in givenness.

e. The theological datum. The problem of theophany could otherwise be stated as that of the theological datum, distinct from an ordinary sense datum. Joseph Rivera distinguishes between "the experience of sense data (philosophy) and the experience of divine data (theology)," suggesting that "theology provides data analogous to sense data," that deliver "the positum of Revelation" (2018, p. 182 , p. 184 , p. 189). The phenomenological question then becomes: "How are divine data, that is, Revelation, mediated to me?" (Rivera, 2018, p. 189). Like Marion, Rivera seems to suggest that Scripture contains some universally accessible theological datum if one only wants to see it. Yet, what could this theological datum possibly be? Benoist's objection is precisely that where Marion sees an extraordinary theological datum, he sees an ordinary sense datum. Indeed, why would Scripture impose itself on us as theological datum (Revelation) and not first as a sense datum (revelation)? Why ask how theological data are mediated to me, rather than how sense data are mediated to me as religious phenomena? Moreover, how could there be theological data at all? Religious phenomena do not consist in theological data imposing themselves on me, but rather in absolutely given sense data being mediated to me as religious phenomena. Only in this way can phenomenology discuss the possibility of revelation, leaving actual Revelation to theology. In doing so, however, both consider the same data, those of experience, that are merely received differently: there is no phenomenologically accessible positum of Revelation; Marion's phenomenology merely shows that absolute givenness is the experiential positum as revelation.

When Marion then proclaims his "historical literalism about the events of the New Testament” (Caputo, 2007, p. 83), Kosky speaks of theophany, and Rivera assumes theological data, we really do "want to believe that it is by design (...) that farewell is thus bid not only to common sense, but to the stuff of phenomena," for "the only tie that binds these citations to whatever kind of experience is religious" (Janicaud, 2000, p. 63). This obsession with theophany indicates to me that the phenomenology at issue here is a phenomenological theology rather than a phenomenological philosophy of religion. Indeed, Marion's phenomenology finds its legitimacy in theology rather than in philosophy: in the will to see, which is nothing other than faith, fidelity to givenness, and inscribes that phenomenology within a logic of faith. Rivera embraces this: "Marion's analysis," he says, "attempts to achieve just this kind of confessional phenomenology. I have no problem with this task." Indeed, according to him, "the future of phenomenology's theological turn resides in the recent trend to use phenomenology as a tool for explication of dogma bound up with a particular faith tradition" (2018, p. 192). This is perfectly fine, if we are prepared to concede to Janicaud that this is "a Christian phenomenology," which has no future as a phenomenological philosophy of religion, because its "properly phenomenological sense must fall away, for a nonbeliever" (2000, p. 67). Since phenomenology is merely a method, I am perfectly willing to do that: Rivera's confessional phenomenology is entirely legitimate as a phenomenological theology that aims at describing theophany, situated within a faith tradition and its associated community of faith (or discourse). Yet, this does not help us in our present questioning, 
which is entwined with the possibility of Marion seeing God where others see nothing.

The question a phenomenological philosophy of religion must ask is thus: how does "the category of faith" (Nancy, 2008a, p.152), as an existential situation, function phenomenologically? How does it render possible the religious phenomenon, in the absence of its undisputed actuality? This is a question about faith, but not from faith. For, as Marion correctly observes, a phenomenological philosophy of religion can only concern itself with the possibility of revelation. Nevertheless, this possibility cannot be established philosophically on the side of the phenomenon alone by giving actuality priority over possibility: in this way, Falque notes, Marion tries to maintain "in the framework of theology what phenomenology holds nevertheless as forbidden - the primacy of the fact over the sense" (2007, p. 194; see also Carlson, 2007, p. 161-162). In order for there to be (the actuality of) Revelation, a subjectivity receptive to revelation, faithful to givenness, is required. Taking this into account requires us to change strategies, as Falque observes:

The essential question today, in phenomenology as in theology, is not uniquely that of the 'phenomenon of revelation' or of 'god' (...). Instead it concerns the human or the receiving subject in his or her capacity-or lack of capacity-to speak about the phenomenon, or God, or whether one starts from the phenomenon itself or from God in the act of self-revelation (the descending ontological way), or starts from the human and the human conditions of existence (in via) rendering impossible all direct access to some beyond (in patria) (the ascending cosmological way/ s). (...) Must we necessarily accuse of an 'anthropological reduction' a phenomenology that would first take 'the human as such,' (...) in our finitude, for the point of departure of its phenomenality? And must we not, on the contrary, hold at once as impossible (...) all the bedazzlement of the 'phenomenon of revelation' that would give itself all at once, almost directly and independently of all the (transcendental) conditions of its reception? (2007, p. 188)

Marion takes the descending ontological way, giving absolute priority to objective givenness over its subjective reception: actuality precedes possibility, determining possibility in terms of actuality; the phenomenon predates the subject, constituting it as witness to revelation. Yet, this approach stumbles regarding the philosophical question about faith. Hence, let's change strategies: philosophically, where actuality is in doubt or reduced, we must limit ourselves to possibility in terms of possibility; not so much ascending, but considering the possibility of ascending, namely subjective faith. Phenomenology, as Falque correctly notes, is not primarily concerned with divinity, but with humanity as such, the conditions of existence shaping experience and situating reason: the biases that make meaningful appearance possible. It is such an account that Jean-Luc Nancy offers.

\section{\$3. The revelation of nothingness}

Nancy is not usually associated with the theological turn, yet has worked in parallel to it. Deeply critical of both Christianity and phenomenology, his work can nevertheless not be understood without reference to both. ${ }^{9}$ Indeed, there is an unconventional phenomenology in Nancy: "a phenomenology that is theological, but not theophanic" (Nancy, 2008a, p. 49). Starting from finite humanity, (in) which infinite divinity opens up: the theological dimension is not experienced, but inferred from those who existin-faith, whose lives bear witness to it. This existential inference and interference of theology in phenomenology, forms, I believe, the future of phenomenological philosophy of religion: a phenomenology that explains how the existential situation of faith structures experience; rather than a phenomenological description of dogma, liturgy and devotion, internal to a particular religious tradition, and therefore to theology. The future belongs to a phenomenology that thinks about faith, but not from faith.

a. The givenness of nothingness. Nancy's problem with Marion is that the latter's "powerful and eloquent proposition does not emerge yet out of a 'self-giving' (and of a 'self-showing') of the phenomenon, whereas I propose here, simply, that nothing gives itself and that nothing shows itself-and that is what is" (Nancy, 2007, p. 123n24). For him, everything that gives (from) itself (se donne), at the same time withdraws (in) itself (s'abandonne) by giving itself (1982, p. 83). Or, as Ashok Collins puts it, "in piercing to the heart of givenness, we encounter the exposure of a patent nothingness" (2015, p. 332): something only exists in and as its own effacement; there is no-thing that is given as itself in pure (phenomenal) self-immanence (Nancy, 2007, p. 102).

For Nancy, reality exists in an infinite circulation of meanings, emerging from a never-ending process of making sense of the world by dwelling in it, and as such merging with it. Phenomenology cannot do justice to this "coming of sense," because reduction aims at stable essences: "there is no epoché of sense," for the epoché is itself a way of making sense of the world and is therefore "already caught up in sense and in the world" (Nancy, 1997, p. 17-18). Hence, whatever gives itself (to a consciousness) also withdraws itself, whatever essence emerges from the world of appearances does so by merging with it: there is no pure meaning at one with itself; rather, it is always internally displaced, divided and shared, absent when fully present (to a consciousness). In other words, what the phenomenological reduction aims at-constructing all meaning as immanently constituted by a consciousness-is impossible because consciousness is always already carried along outside of itself by the movement of sense in which it is caught up. This movement can never be appropriated by a consciousness, but is nevertheless always exposed in consciousness' engagement with the world, in its making sense of the world. ${ }^{10}$ Therefore, Nancy says, "nothing presents itself," which spells "the end of a phenomenology in general, albeit that of the unapparent," including that of givenness. Indeed, "the present does not present itself," the given does not give itself, "and [yet] it is no less exposed. It is nothing other than that, and that is what it falls to us to think henceforth" (2007, p. 72).

Theologians know this as the problem of the divine names: in naming God, he escapes us, for God exceeds any singular name. How are we then to think about God? Well, we shouldn't. In naming the abysses of thinking God, Nancy says, "we fill in the abysses by attributing a bottom to them, and we blaspheme (...) the name of God by making it the name of something" (1991, p. 113). Indeed, God escapes signification, is no-thing. We must allow God to bask in the glory of his withdrawal, instead of summoning (undoing) him by naming him: to let him open up (within) the world as the abyss on which it rests, nothing. God does not give himself; yet gives himself as nothingness. How are we to think this?

Nancy replaces divine names with divine places: where for Marion God is given as superabundant givenness; for Nancy, it is as the lacking, empty nothingness, of such a given (name) that God shows himself, namely in withdrawing into himself and effacing himself: the lack of divine names is a place for divinity "to withhold itself, and as a consequence, thereby to offer itself, to offer itself in reserve, both as its own reserve and as its own withdrawal" (Nancy, 1991, p. 120). God may then not be given (a 
name), but he is nevertheless exposed (in places) as the breaches in immanence we experience. This place where God is exposed, where he shows himself by hiding himself, is finite humanity, the conditions of existence: "Here (...) divinity lets itself be seen, manifestly invisible and invisibly manifest. God reveals himselfand God is always a stranger in all manifestation and all revelation. Revelation (...) is not a presentation, or a representation: it must be the evidence of the possibility (never the necessity) of a being-unto-god. What there is revelation of is not 'God,' as if he were something that can be exhibited (...), it is rather the unto-God (l'à-Dieu) or being-unto-god" (Nancy, 1991, p. 124). The possibility of being-unto-God sets me in-the-world in a certain way, for "the god expels man outside of himself" (Nancy, 1991, p. 147). Namely, it sets me in relation to God, opens me unto God: "The divine is that, or he, with which or with whom man finds himself involved in a certain relation, be it one of presence or of absence, one of appearance (parution) or disappearance" (Nancy, 1991, p. 132). In doing so, it sets me in relation to the nothing, for being-unto-God is being-untonothing (Nancy, 1991, p. 126). Hence, the divine place is the subjectivity (in) which divinity opens up as the possibility of being-unto-God, putting it outside-of-itself and allowing it to-beitself. A phenomenological philosophy of religion finds (the possibility of) God in, must be directed at, the subjectivity characterised by (the possibility of) faith, for this forms "the necessary relation to the nothing" (Nancy, 2008b, p.12).

b. The fidelity to nothingness. Whereas Marion understands faith as the will to see, fidelity to givenness, to what there is to be seen; Nancy, in line with Caputo, understands it as fidelity to nothingness, keeping open the void, a seeing (nothing) where nothing is to be seen (Nancy, 2008a, p. 154): faith opens up "where it is no longer a sacred presence that assures and guarantees, but the fact itself (...) of not being assured by any presence" (Nancy, 2008a, p. 55). Faith is "a relation to God," but only "to the extent that God and his love are not present, shown," because in relating to it, the only access it provides is "an access, consequently, to that which cuts off or withdraws access," effacing itself in giving itself (Nancy, 2008a, p.62, p. 152). There is "no standpoint outside of God," as Rudolf Bultmann puts it, "and thus God cannot be spoken of in general statements, general truths, which are true without reference to the concrete existential situation of the speaker" (1969, p. 53, trans. mod.). Faith is thus a relation to nothing, to a presence as absent and an absence as present: "this faith," Nancy suggests, "is the outside opening in itself a passage toward the inside," it "does not consist in recognising the known but in entrusting oneself to the unknown" (2008a, p. 54; 2008b, p. 28). Faith is nothing but beingunto-nothing.

Hence, it is not about believing anything, but rather, like Nietzsche says, "a doing, above all a not-doing-much, a different being" (Nietzsche, 2005, p. 35; Nancy, 2008a, p. 52): being-untoGod. Only here does God manifest himself, in this different being, this existence-in-faith, of those that succeed in seeing him, seeing what is not there to be seen: "Revelation (...) reveals that there is nothing to show, nothing to make appear out of the tomb, no apparition, and no theophany or epiphany of a celestial glory" (Nancy, 2008b, p. 45). That is to say, the theological dimension opens up, manifests itself, within the subject as the nothingness to which it relates through faith, and in doing so receives itself as subject, exists entirely in and as this relation. Nancy has expressed this idea in the language of Marion's theory of saturated phenomena:

The greatest spiritual and theological analyses of the Christian faith show that faith is rather (...) the adhesion to itself of an aim without other. I will say, in phenomenological terms, the adhesion to itself of an aim without a correlative object, or with no fulfilment of sense but that of the aim itself. One could perhaps say that faith is pure intentionality, or that it is the phenomenon of intentionality as a self-sufficient phenomenon, as a 'saturated phenomenon,' in Jean-Luc Marion's sense. I understand perfectly well that Marion, in speaking of 'saturated phenomena,' is not talking about a phenomenon like faith, but rather of phenomena that would offer themselves as faith, or that would entail faith; nevertheless, I leave open the question of whether faith might not be such a 'saturated phenomenon,' or even, perhaps, saturation itself (2008a, p. 152-153).

Nancy's understanding of faith as the adhesion to itself of an aim without fulfilment other than itself resonates with Caputo's critique of Marion. Marion's phenomenology is hyperbolic, he suggests, for it is built upon an excess, not of intuitive givenness, but of intention: faith is not the will to see what there is to be seen, but the desire (the will) to see something when there is nothing to be seen. "Now there is phenomenology here," Caputo says, "but it is a phenomenology of faith, which is an excess in the order of intention beyond fulfilment (...) and not one of saturated givenness, which is the same for believers and nonbelievers, otherwise it is not a phenomenological datum" (2007, p. 87), but a theological datum. Nancy embraces this hyperbolic reading of Marion, reconfiguring his phenomenology: it is the subjectivity or existence that can see where there is nothing to see, because it exists in faith, that thus becomes the site or the place of phenomenality. For it is there that the nothing which gives itself is made sense of and thus shows itself. The "subjective and existential adherence" (Nancy, 2008a, p. 154) of faith becomes itself the saturated phenomenon, saturation itself, precisely because saturation is not a characteristic of what appears, but of how it appears to a situated subject: saturation describes what happens to the subject, its horizons getting overwhelmed, and not the nature of the object of experience. This is perhaps why Marion at some early instances speaks of a saturating phenomenon, rather than a saturated phenomenon (see Marion, 2017b). Nancy picks up on this by suggesting that the how (faith) is coextensive with the what (excess) of revelation: God is revealed in and as the lives of those whom he reveals himself to in virtue of their faith. It is thus a question of thinking how faith allows for the following: "how man appears to god, in the god, how the god appears to man, in man, and how that itself is totally unapparent" (Nancy, 1991, p. 139). God is revealed in and as being-unto-God.

c. The experience of nothingness. In an essay entitled Noli me tangere, containing a meditation on the passage from the Gospel of John known under the same name, Nancy then attempts to think God as revealed in and as a particular being-unto-God. The Gospel passage relates how Mary Magdalene finds Jesus' tomb empty. The risen Christ then appears to her, but she does not recognise him, seeing a gardener instead. Once he calls her by her name, everything changes. Jesus then instructs her not to touch him, but instead to go tell the disciples that she has seen him. Nancy wonders why Mary Magadalene did not recognise Jesus initially. What did she see and when?

Reflecting on this, he considers the various artistic depictions of this episode: the resurrection itself, though absent from the Gospels, figures prominently in the history of art and is usually presented as a spectacular show of divine power, rendering visible an event "nowhere given to be seen," in an attempt "to confront the invisible head on (...) and to take the gesture of seeing and of making seen to the point of dazzling the gaze and rendering the canvas incandescent" (Nancy, 2008b, p. 22). Encounters with the arisen, however, are presented in a lower key. In Albrecht Dürer's 
woodcut depicting the passage at issue, for example, there are no markers of Jesus' divinity: he appears without halo, but with shovel and sun hat. Nothing visible suggests that the man depicted is anything but a gardener. Nancy therefore concludes that, regardless of the revelation, "there is nothing changed in his appearance. Thus there is nothing to change in Mary Magdalene's seeing, and this seeing is not a mistake" (2008b, p. 30). Indeed, nothing is revealed, there is nothing to see. Dürer hints at this by having the sun illuminate the empty tomb and Jesus' back: it is "in the emptiness or in the emptying out of presence that the light shines. And this light does not fill in that emptiness but hollows it out even more, since in Dürer we could venture to discern it in the proximity of the sun to the gardener's (the gravedigger's?) shovel" (Nancy, 2008b, p. 26). Revelation does not reveal anything to be seen by giving it, but precisely the absence and withdrawal of any such thing as the nothingness that leaves me alone with my faith.

The resurrection serves as Nancy's paradigmatic example of this revelation of nothingness. As risen, Christ is neither dead nor alive: the divine putrefaction Nietzsche's madman raves about has not infected the air, yet he is obviously not alive (Nancy, 2008b, p. 41). He describes this peculiar state in which Christ appears as follows:

$\mathrm{He}$ is the same without being the same, altered within himself. Is it not thus that the dead appear? Is it not this alteration, at once imperceptible and striking - the appearing of that which or of he who can no longer properly appear, the appearing of an appeared and disappearedthat most properly and violently bears the imprint of death? The same is no longer the same; the aspect is dissociated from the appearance; the visage is made absent right in the face; the body is sinking into the body, sliding under it. The departing (la partance) is inscribed into presence, presence is presenting its vacating (son congé). He has already left; he is no longer where he is; he is no longer as he is. He is dead, which is to say that he is not what or who he, at the same time, is or presents. He is his own alteration and his own absence: He is properly only his impropriety (2008b, p. 28).

Christ appears as neither alive nor dead, present nor absent. He is his departing, the presence of absence, death opening up within life, light illuminating the empty darkness of the tomb. This is not something that gives itself to be seen. Hence, Mary Magdalene does not see the risen Christ, for he is "what is not seen and what nonetheless shines," his glory "radiates only for eyes that know how to see, and those eyes see nothing but the gardener," it "shines only insofar as it is received and transmitted" (Nancy, 2008b, p. 17, p. 46).

How does Mary Magdalene find Christ in the gardener? Not by seeing differently, like Marion would have it, as if the gardener is a guise to be seen through; but by relating differently to what is (not) to be seen, a different being. It is thus not a question of "seeing in the darkness, that is, in spite of it," but of "opening one's eyes in the darkness and of their being overwhelmed by it, or it is a question of sensing the insensible and of being seized by it" (Nancy, 2008b, p. 42). This is a matter of the subject receiving revelation, who "must have ears to hear what the gardener says, eyes to see (into) the radiant emptiness of the sepulcher, a nose to smell what smells of nothing" (Nancy, 2008b, p. 46). In the case of Mary Magdalene, she can recognise Christ in the gardener without seeing him, because she does not need to see him, she has faith because nothing gives itself to be seen: "She believes because she hears. She hears the voice that says her name. She hears this voice that contradicts the appearance of the gardener but, even so, it is not said that her seeing changes. She is responding only to the voice of he who maintains the same appearance. (...) Mary's faith consists in her trust that he who calls her calls no other than her and that there is a fidelity to this naming" (Nancy, 2008b, p. 29-30). It is thus the existential situation of faith, Mary Magdalene's trust in Jesus actually being there though nowhere to be seen, her being-unto-God, that serves as the condition of possibility for the divine to become phenomenal. "That is why," Nancy says, "one must already have in order to receive: precisely, one must have the receptive disposition" of faith $(2008 \mathrm{~b}, \mathrm{p} .6)$.

Interestingly, Nancy suggests that the site of phenomenality, the place where divinity enters phenomenality, is not what is given to Mary Magdalene but rather her faith, her subjective existence itself: in the departing confronting her, "there is revelation, but it is not he who leaves that reveals; it is she upon whom the task is conferred to go and announce his departure" (2008b, p. 48). Hence, the phenomenology at issue is not theophanic, it does not render the divine phenomenal to a consciousness, just like Mary Magdalene sees nothing but a gardener; but it is theological in its description of how faith allows her to see in the darkness, to make sense of the nothing that is there to be seen. Here, Nancy detects a similarity between Abraham and Mary Magdalene: "like Abraham," he says, "Mary does not demonstrate her faith through statements, hypotheses, or calculations. She leaves" (2008b, p. 30). She did as Jesus asked of her: leaving to go tell the good news of the resurrection. Kierkegaard similarly observes that Abraham did not doubt when confronted with a similar paradox, rather "he drew the knife" (1985, p. 55). If God reveals himself in the stories of Abraham and Mary Magdalene, it is not to them that he appears in an experience of theophany, for they do not require this since they have faith; but rather in them, the lives of which the stories tell that are a testament to their being-unto-God, their faith, and thus to God himself. These lives-of-faith are the real saturated phenomena, saturation itself. Those who fail to have faith can only look upon them in awe, be dazzled by them: these lives are incomprehensible because they are unconditioned, detached, from worldly reason(s) and instead animated by faith; going beyond what is humanly possible for the human being (a father sacrificing his son). ${ }^{11}$ As such, phenomenologically, God must be seen as "an expression of our existence" (Bultmann, 1969, p. 60).

\section{Conclusion-'philosophe avant tout'}

The attempt at outlining a phenomenological philosophy of religion, as opposed to a phenomenological theology, that I have developed over the course of these paragraphs, may appear as quaintly old fashioned. Is the phenomenology of religion not the prime example of how it has become impossible to clearly distinguish philosophy from theology? Indeed, I have not picked up the gauntlet, thrown down by Falque in an obvious reference to Marion, to think how "one is more of a philosopher by being at the same time a theologian, in the unity of the same person, than by always trying to pass as nothing but a philosopher while in fact also practicing theology" (2016a, p. 123).

Falque's exploration of the borderlands of philosophy and theology, an investigation into how one can be transformed by the other, presents a fundamental challenge to the question that has dominated French philosophy (of religion) ever since the 1988 essay by Marion I opened this article with: is a phenomenological philosophy of religion possible as distinct from a phenomenological theology? Falque's point is not so much that such a philosophy of religion is impossible, but rather that it might not be desirable. ${ }^{12}$ In doing so, he places himself firmly within the debate concerning the question first raised by Marion, whilst at the same time attempting to move on from it. I therefore see no reason why this question would not dominate the future of French philosophy of religion as much as it has done in its recent past. This is why, despite Falque's important challenge, I have 
found it worthwhile to attempt to answer Marion's question by providing a sketch of how such a phenomenological philosophy of religion might be possible.

This sketch, however, has attempted to avoid any naivety about the very real entanglement of philosophy with theology at the heart of many phenomenologies of religion. In that sense, what I have suggested fits entirely within Falque's framework insofar as it asks the philosopher to become aware of the fact that "the starting points are all the more philosophical when the endpoints are theological. This position can be summarised as the principle of 'the philosopher before all else (philosophe avant tout),' which should be adopted today not against theology but, on the contrary, for it" (Falque, 2016a, p. 149). In being confronted with infinite divinity as its object, the philosopher realises that, insofar as he is a philosopher, he can only proceed from below, using as his point of departure "the human per se-that is, from the horizon of the pure and simple existence of the human" (Falque, 2016a, p. 122-123). Indeed, "rather than in terms of their objects," Falque continues, "philosophy and theology are distinct in terms of their points of departure," what I have called their respective existential situations, the presuppositions that orientate and constitute their respective discourses by means of a certain decision (or, indeed, a certain faith). More specifically, "the former (...) starts from 'below' and simply takes as 'possible' what the second recognises as 'actual' in starting from 'above'" (Falque, 2006, p. 207-208; 2016a, p. 122-128). Otherwise put, philosophy (of religion) considers religious experience in terms of how it is structured or made possible by faith (or existence-in-faith) and in that sense starts from below, for it approaches (possible) experience in terms of a particular determination of human finite existence (its analysis of experience is about or in terms of faith); theology, however, considers religious experience as only accessible through faith and as such starts from above, precisely because its approach to the (actual) experience that it considers to be theophanic already assumes the presence of the infinite within it (it analyses experience from within the perspective of faith). ${ }^{13}$ Philosophy then comes before all else, just like possibility comes before actuality, in the sense that "no theologoumenon has any meaning outside outside of a lived experience or a philosophical 'existential,' which gives it meaning (...). In sum, it should be clear that a phenomenology from below precedes and grounds any theology from above" (Falque, 2016a, p. 124).

I have thus suggested that the future of philosophy of religion in its phenomenological style lies, not in Marion's phenomenology of givenness, for it operates from faith and is therefore inscribed in a theo-logic of faith in virtue of its theo-phanic aim; but rather in Nancy's phenomenology of existence, which inquires about faith as the existential situation in which phenomenological reason finds itself and allows it to operate. Hence, we could conclude with Bultmann that "it is therefore clear that if a man will speak of God, he must evidently speak of himself' (1969, p. 55), namely his finite humanity. Or, we might follow Nancy, who concludes with the more phenomenological language of an essay by Gérard Granel: "If there is something certain here, it is that perceptual experience is $m y$ experience. It is (...) the experience-of-me. To suppose that someone else could look through my eyes is absolute nonsensenot because my eyes 'belong to me,' but because the gaze is not made 'by' the eyes. The gaze is given to me on the basis of the very thing I am looking at, as also are my eyes, and even 'me.' Decidedly." (2008, p. 171, my emphasis).

Received: 17 June 2018 Revised: 5 October 2018 Accepted: 10 October 2018

Published online: 30 October 2018

\section{Notes}

1 My approach is similar to, though more critical than, that of Christina Gschwandtner (2016, p. 64-69), who has also read (some) of these essays together.

2 For both a recognition of the legitimacy of this question, as well as an interesting way of developing a phenomenology of mysticism regardless, see Steinbock, 2007, p. $17-32$, p. $115-147$.

3 These two points are also made eloquently by Emmanuel Falque in his Crossing the Rubicon: The Borderlands of Philosophy and Theology (2016a, p. 80-88) as the 'prejudice of the absence of prejudices' $(\$ 11)$ and the idea of 'a belief at the origin' $(\$ 10)$. Falque shows how this means that the phenomenological approach to the world always runs into a certain kind of irreducible faith, whether this faith is philosophical or religious: "The idea of an original faith in the world, or rather trust in the belief that I have of the world," he writes, "makes the world paradoxically the highest and the most certain of truths in an originary attitude of trust rather than mistrust. That this faith may be philosophical and not only religious is one of the great lessons of phenomenology, which theology today would gain from investigating, albeit to let itself be transformed in the process" (83). In that sense, he says, he is picking up on Heidegger's description of faith in The Phenomenology of Religious Life (2010, p. 248) as a phenomenologically relevant "primordial doxa, toward which the others are referred back in a certain way." This primordial doxa thus functions in the same way as what Kierkegaard calls decision.

4 Whereas Kierkegaard understands the act of decision first and foremost in a profoundly ontologically way, its broader theological and phenomenological reach is wonderfully summarised by Falque (2016a, p. 111): "Deciding is not choosing but responding. The person who decides is never first; he is always second. One does not decide a priori but only a posteriori."

5 The other three principles are: (1) Heidegger's 'so much appearance, so much being' (Soviel Schein-soviel Sein) (1996, p. 36); (2) Husserl's principle of principles; and, (3) Husserl's 'Back to the things themselves!'. Marion has since explicitly adopted this didactic frame offered by Henry (see 2002a, p. 7-19; 2002b, p. 17).

6 This is not to say that all phenomena should be thought according to the model of absolute givenness, according to the regime of revelation. Marion admits that there are various degrees of givenness, but all these degrees depend on the possibility of absolute givenness (see Marion, 2002a, p. 179-247; Gschwandtner, 2014).

7 Marion would strongly contest how I describe his position here. Indeed, he often paraphrases Heidegger, who declares in the famous seventh paragraph of Being and Time (1996, p. 38), taking his cue directly from Husserl, that for the phenomenologist "Higher than actuality stands possibility. We can understand phenomenology solely by seizing upon it as a possibility." The point that Marion wants to make is that though the absolute phenomenon of revelation might lack actuality, this does not count against its claim to phenomenality, since possibility determines actuality. Otherwise put, if experience is thus defined so as to exclude absolute phenomena from the outset, if the phenomenal field is restricted a priori; then of course these phenomena will never appear in experience, yet this has nothing to do with their actuality. The problem here, however, is that Marion already seems to assume the actuality of this absolute phenomenon: what is the point of thinking the possibility of the impossible, of freeing the possibility of revelation, of extending phenomenality beyond what is seen to what is to be seen; if the actuality of the impossibility is not already assumed, from which it would indeed follow that the conditions of possibility need to be redefined in order to be adequate to this impossible actuality? Why collapse all formal conditions of possible experience into material ones if one does not already have a certain actual (and therefore, it follows, it must also be possible) experience in mind that would exceed those formal conditions? At most, possibility only precedes actuality within Marion's framework when this is understood as possibility de facto but not possibility de jure. The point of all this, as I will develop in what follows, is that Marion's phenomenology is theological (because it starts from actuality) rather than philosophical (which starts from possibility). Yet, curiously, Marion nevertheless identifies this dividing line correctly.

8 Of course, the category of saturated phenomena is not entirely coextensive with theophanic phenomena: as Kosky rightly emphasises (2000, p. 116), there are also aesthetic (the sublime) and philosophical (the infinite) saturated phenomena. Yet, nevertheless, the phenomenon par excellence remains a special type of saturated phenomenon, the "paradox of paradoxes," namely revelation, because unlike the others it is "saturated to the second degree" (Marion, 2002a, p. 247).

9 For two detailed studies of Nancy's relation to both traditions, see respectively, Watkin, 2011 and Watkin, 2009; in addition to Lueck, 2015 and Watkin, 2015. On Nancy's relation to the theological turn in general, and Marion in particular, see: Collins, 2015; James, 2012, p. 35, p. 38; Horner, 2009; ten Kate, 2008; Alexandrova et al. 2012, p. 33-36; and Hackett, 2015.

10 The notion of sense (sens) within Nancy's work is complex and all-encompassing. What Nancy means by it can perhaps most straightforwardly be summed up as being itself, though this must always be seen as a social being-with. In that sense, it is perhaps better understood as the act and the event of being that happens between us. For it is through what happens between us, our relations, our conversations, our interpretations, that meaning is created and a world comes to be. Indeed, Nancy says, we are meaning (2000, p. 1-5): sense is the meaning that we are, that we share, that 
we expose. Sense, in other words, is ek-sistence: "Being as such (...) is no more 'present' in Dasein than anywhere else (...); rather, it is the 'that there is' of being as sense. This sense is not a property of the 'that there is.' It properly is (or makes) the 'that there is' as such. It engages it and engages itself in it: 'that there is' is what is at stake in sense. Being, absolutely and rigorously considered as such (which also means (...) considered according to its unnominalized value as a verb-being is or exists being, it 'makes' them be, makes them make-sense), is essentially its own 'engagement' as the action of sense" (Nancy, 2003, p. 177). Indeed, because this being as ek-sistence is fundamentally being-outisde-of-itself, there can never be any real (phenomenal) immanence or (divine) transcendence. As such, sense is never given, or is given precisely as nothingness: "it is precisely this darkness, this being-not-given of sense, that leads onto the proper dimension of sense as what is, in being and of being, desired and to be accomplished (acted out). In the ordinary impropriety of simple existing, being's propriety of sense-which consists precisely in having to make sense, and not in the disposition of a given proper sense-both dissimulates and reveals itself" (Nancy, 2003, p. 179).

11 It is precisely this bedazzlement, this horror and admiration, felt by the pseudonymous author of Kierkegaard's Fear and Trembling, that forms the very theme of the book.

12 Whereas Janicaud describes philosophy's turn to theology as treason, Falque speaks of what a great honour it is for philosophy to be able to fulfil this move and describes it almost as a homecoming: "Today philosophy seems to have forgotten the honour of the theological. By dint of claiming his autonomy, the philosopher became independent and then separated from the theological. Now long after the divorce has been completed, he returns to his old loves as to his first spouse" (2016a, p. 129). Elsewhere he describes how this means that "a 'conversion' of philosophy by theology thus becomes necessary, not to demand of the former that she submits herself to the latter, nor a 'treason'; [but rather] for the philosopher to be thus elevated to the rank of theologian" (2006, p. 208-209).

13 Notice that whilst phenomenological theology and phenomenological philosophy of religion do indeed consider the same object (namely, theophany or religious experience), but simply in different ways (from above or from below, from faith or in terms of faith); depending on which position one takes (that of the philosopher or that of the theologian), the objects of these respective disciplines might seem distinct after all: for the theologian, the philosopher considers the general structure or conditions of possible experience; for the philosopher, the theologian considers actual experiences that do not enter his or her proper field of view. It is perhaps here that Falque's dictum proves to be immensely powerful: the more we theologise, the better we philosophise.

\section{References}

Alexandrova A, Devisch I, ten Kate L, van Rooden A (2012) Re-opening the Question of Religion: Dis-enclosure of Religion and Modernity in the Philosophy of Jean-Luc Nancy. In: Alexandrova A, Devisch I, ten Kate L, van Rooden A (eds) Re-treating Religion: Deconstructing Christianity with JeanLuc Nancy. Fordham University Press, New York, p 22-40

Barth K (1982) Die christliche Dogmatik im Entwurf. Theologischer Verlag, Zürich Benoist J (2001) L’idée de phénoménologie. Beauchesne, Paris

Benson BE (2010) Introduction. In: Benson BE, Wirzba N (eds) Words of Life: New Theological Turns in French Phenomenology. Fordham University Press, New York, p 1-12

Bultmann R (1969) What Does It Mean to Speak of God? (Trans. by LP Smith). In: Funck RW (ed.) Faith and Understanding I. Harper \& Row, London, pp 53-65

Caputo JD (2007) The Hyperbolization of Phenomenology: Two Possibilities for Religion in Recent Continental Philosophy. In: Kevin Hart (ed) CounterExperiences: Reading Jean-Luc Marion. University of Notre Dame Press, Notre Dame, p 67-93

Caputo JD (2013) Truth: The Search for Wisdom in the Postmodern Age. Penguin, London

Carlson TA (2007) Blindness and the Decision to See: On Revelation and Reception in Jean-Luc Marion. In: Kevin Hart (ed) Counter-Experiences: Reading Jean-Luc Marion. University of Notre Dame Press, Notre Dame, p 153-179

Collins A (2015) Towards a Saturated Faith: Jean-Luc Marion and Jean-Luc Nancy on the Possibility of Belief after Deconstruction. Sophia 54:321-341

de Vries H (1999) Philosophy and the Turn to Religion. Johns Hopkins University Press, Baltimore

Falque E (2003) Phénoménologie de l'extraordinaire. Philosophie 78(3):52-76

Falque E (2006) Philosophie et théologie: Nouvelles frontières. Études 404 (2):201-210

Falque E (2007) Larvatus pro Deo: Jean-Luc Marion's Phenomenology and Theology. (Trans. by R Horner). In: Kevin Hart (ed.) Counter-Experiences: Reading Jean-Luc Marion. University of Notre Dame Press, Notre Dame, pp 181-199

Falque E (2008) Dieu, la chair et l'autre: D'Irénée à Duns Scot. Presses Universitaires de France, Paris
Falque E (2016) Crossing the Rubicon: The Borderlands of Philosophy and Theology. (Trans. by R Shank). Fordham University Press, New York

Falque E (2016) The Collision of Phenomenology and Theology. (Trans. by A Wells). In: Dika TR, Hackett WC (eds) Quiet Powers of the Possible: Interviews in Contemporary French Phenomenology. Fordham University Press, New York, pp 211-227

Granel G (2008) Far from Substance: Wither and to What Point? (Essay on the Ontological Kenosis of Thought since Kant). (Trans. by B Bergo, G Malenfant and MB Smith). In: Dis-Enclosure: The Deconstruction of Christianity. Fordham University Press: New York, pp. 163-174

Gschwandtner CM (2014) Degrees of Givenness: On Saturation in Jean-Luc Marion. Indiana University Press, Bloomington

Gschwandtner CM (2016) Marion and Theology. Bloomsbury, London

Hackett WC (2015) Jean-Luc Marion. In: Gratton P, Morin ME (eds) The Nancy Dictionary. Edinburgh University Press, Edinburgh, p 153-154

Heidegger M (1996) Being and Time. (Trans. by J Stambaugh). State University of New York Press, Albany

Heidegger M (2010) The Phenomenology of Religious Life. (Trans. by M Fritsch and JA Gosetti-Ferencei). Indiana University Press, Bloomington

Henry M (2015) The Four Principles of Phenomenology. (Trans. by J Rivera and GE Faithful). Cont Philos Rev 48(1):1-21

Holzer V (1999) Phénoménologie radicale et phénomène de révélation. Transversalités: Rev De l'Institut Cathol De Paris 70:55-68

Horner R (2009) On Faith: Relation to an Infinite Passing. Aust eJournal Theol 13 (1): $1-21$

Husserl E (1982) Ideas Pertaining to a Pure Phenomenology and to a Phenomenological Philosophy. First Book: General Introduction to a Pure Phenomenology. (Trans. by F Kersten). Martinus Nijhoff, The Hague

Husserl E (2001) Logical Investigations. (Trans. by Dermot Moran). 2 Vols. Routledge, London

James I (2012) The New French Philosophy. Polity Press, Cambridge, Polity Press Janicaud D (2000) The Theological Turn in French Phenomenology. (Trans. by BG Prusak). In: Phenomenology and the 'Theological Turn': The French Debate. Fordham University Press, New York, p 1-103

Kierkegaard S (1985) Fear and Trembling. (Trans. by A Hannay). Penguin, London Kierkegaard S (2009) Concluding Unscientific Postscript. (Ed. and trans. by A Hannay). Cambridge University Press, Cambridge

Kosky JL (2000) Translator's Preface-The Phenomenology of Religion: New Possibilities for Philosophy and for Religion. In: Phenomenology and the 'Theological Turn': The French Debate. Fordham University Press: New York, pp. 107-120

Lueck B (2015) Phenomenology. In: Gratton P, Morin ME (eds) The Nancy Dictionary. Edinburgh University Press, Edinburgh, p 176-178

Marion JL (1990) The Other First Philosophy and the Question of Givenness. (Trans. by JL Kosky). Crit Inq 25(4):784-800

Marion JL (1998) Reduction and Givenness: Investigations of Husserl, Heidegger, and Phenomenology. (Trans. by TA Carlson). Northwestern University Press, Evanston

Marion JL (2002a) Being Given: Toward a Phenomenology of Givenness. (Trans. by JL Kosky). Stanford University Press, Stanford

Marion JL (2002b) Phenomenology of Givenness and First Philosophy. (Trans. by R Horner and V Berraud). In: In Excess: Studies of Saturated Phenomena. Fordham University Press, New York, pp. 1-29

Marion J-L (2008a) The Possible and Revelation. (Trans. by CM Gschwandtner) In: The Visible and the Revealed. Fordham University Press, New York, pp. $1-17$

Marion J-L (2008b) The Saturated Phenomenon. (Trans. by TA Carlson). In: The Visible and the Revealed. Fordham University Press, New York, pp. 18-48

Marion JL (2008c) Metaphysics and Phenomenology: A Relief for Theology. (Trans. by TA Carlson). In: The Visible and the Revealed. Fordham University Press, New York, pp. 49-65

Marion JL (2008d) The Banality of Saturation. (Trans. by JL Kosky). In: The Visible and the Revealed. Fordham University Press, New York, pp. 119-144

Marion J-L (2017a) 'They Recognized Him and He Became Invisible to Them'. Trans. by SE Lewis. In: Believing in Order to See: On the Rationality of Revelation and the Irrationality of Some Believers. Fordham University Press, New York, pp. 136-143

Marion JL (2017b) Nothing is Impossible for God. Trans. by CM Gschwandtner. In: Believing in Order to See: On the Rationality of Revelation and the Irrationality of Some Believers. Fordham University Press, New York, pp. $87-101$

Nancy JL (1982) Le partage des voix. Galilée, Paris

Nancy JL (1991) Of Divine Places. (Trans. by Michael Holland). In: Connor P (ed) The Inoperative Community. University of Minnesota Press, Minneapolis, $\mathrm{p}$ $110-150$

Nancy JL (1997) The Sense of the World. (Trans. by JS Librett). University of Minnesota Press, Minneapolis 
Nancy JL (2000) Being Singular Plural. (Trans. by RD Richardson and AE O’Byrne). Stanford University Press, Stanford

Nancy JL (2003) A Finite Thinking. (Trans. by S Sparks). Stanford University Press, Stanford

Nancy JL (2007) The Creation of the World or Globalization. (Trans. by F Raffoul and D Pettigrew). State University of New York Press, Albany

Nancy JL (2008a) Dis-Enclosure: The Deconstruction of Christianity. (Trans. by B Bergo, G Malenfant and MB Smith). Fordham University Press, New York

Nancy JL (2008b) Noli me tangere: On the Raising of the Body. (Trans. by S Clift, PA Brault and M Naas). Fordham University Press, New York

Nietzsche F (2005) The Anti-Christ, Ecce Homo, Twilight of the Idols, And Other Writings. (Trans. by Judith Norman). Cambridge University Press, Cambridge

O'Leary JS (2018) Phenomenology and Theology: Respecting the Boundaries. Philos Today 62(1):99-117

Prusak BG (2000) Translator's Introduction. Phenomenology and the 'Theological Turn': The French Debate. Fordham University Press, New York, p 1-15

Rivera J (2018) The Myth of the Given? The Future of Phenomenology's Theological Turn. Philos Today 62(1):181-197

Schrijvers J (2011) Ontotheological Turnings? The Decentering of the Modern Subject in Recent French Phenomenology. State University of New York Press, Albany

Simmons AJ (2010) Continuing to Look for God in France: On the Relationship Between Phenomenology and Theology. In: Benson BE, Wirzba N (eds) Words of Life: New Theological Turns in French Phenomenology. Fordham University Press, New York, p 15-29

Simmons AJ (2011) God and the Other: Ethics and Politics after the Theological Turn. Indiana University Press, Bloomington

Simmons AJ, Benson BE (2013) The New Phenomenology: A Philosophical Introduction. Bloomsbury, London

Smith JKA (1999) Liberating Religion from Theology: Marion and Heidegger on the Possibility of a Phenomenology of Religion. Int J Philos Relig 46(1):17-23

Steinbock AJ (2007) Phenomenology and Mysticism: The Verticality of Religious Experience. Indiana University Press, Indianapolis

ten Kate L (2008) Intimate Distance: Rethinking the Unthought God in Christianity. Sophia 47(3):327-343

Vattimo G (2016) Of Reality: The Purposes of Philosophy. (Trans. by RI Valgenti). Columbia University Press, New York

Watkin C (2009) Phenomenology or Deconstruction?: The Question of Ontology in Maurice Merleau-Ponty, Paul Ricoeur and Jean-Luc Nancy. Edinburgh University Press, Edinburgh

Watkin C (2011) Difficult Atheism: Post-Theological Thinking in Alain Badiou, Jean-Luc Nancy and Quentin Meillassoux. Edinburgh University Press, Edinburgh
Watkin C (2015) Christianity. In: Gratton P, Morin ME (eds) The Nancy Dictionary. Edinburgh University Press, Edinburgh, p 44-48

Welten R, Jonkers P (eds) (2005) God in France: Eight Contemporary French Thinkers on God. Peeters, Leuven

\section{Data availability}

Data sharing not applicable to this article as no datasets were generated or analysed during the current study.

\section{Acknowledgements}

I am very grateful to Professor Emmanuel Falque for reading an earlier version of this article and his kind words of encouragement. As I hope any reader will notice, the discussion between Jean-Luc Marion and Jean-Luc Nancy I set up here, takes place entirely within the shadow of Professor Falque's new and exciting work on the relationship between phenomenology, philosophy and theology.

\section{Additional information}

Competing interests: The authors declare no competing interests.

Reprints and permission information is available online at http://www.nature.com/ reprints

Publisher's note: Springer Nature remains neutral with regard to jurisdictional claims in published maps and institutional affiliations.

(c) (i) Open Access This article is licensed under a Creative Commons Attribution 4.0 International License, which permits use, sharing, adaptation, distribution and reproduction in any medium or format, as long as you give appropriate credit to the original author(s) and the source, provide a link to the Creative Commons license, and indicate if changes were made. The images or other third party material in this article are included in the article's Creative Commons license, unles indicated otherwise in a credit line to the material. If material is not included in the article's Creative Commons license and your intended use is not permitted by statutory regulation or exceeds the permitted use, you will need to obtain permission directly from the copyright holder. To view a copy of this license, visit http://creativecommons.org/ licenses/by/4.0/

(c) The Author(s) 2018 